\title{
1. The Court as an offspring of centuries of peace with justice
}

\section{JUSTICE MAY BE BRED IN THE BONES OF HUMANKIND, BUT PROGRESS IS SLOW}

The International Criminal Court (ICC), which came into operation on July 1, 2002 , is the offspring of more than five centuries of humanity struggling to link peace with justice. For that reason, it is absurd to pit the Court at the centre of a peace versus justice dilemma.

This first chapter will discuss how the lessons of history demonstrate the link between the fight against impunity and the prevention of the most serious international crimes. However, as Chapter 5 will discuss, the concept of prevention discussed in this work does not involve the traditional concepts of specific and general deterrence but offers up the alternative view of prevention as the creation of a global moral and legal culture that promotes the outlawing of impunity and the accordance of pariah status to those who fall outside this evolving global culture.

Even before the modern era of nations and positive domestic and international law, we have seen in the slow progress of humankind a persistent view that even in the bloodlust of war, there had to be limits to what constituted a legitimate war and what men in arms could do to both combatants and those not in the furor of battle. The concepts of justice in war and justice for war, termed jus in bello and jus ad bello, can be traced to ancient Greek and Roman philosophers and the teachings in the Old Testament, transformed again in the natural law teachings of Saint Augustine regarding what constitutes a "just war.'”

In this evolution of principles of just war or justice in war through the pre-modern era, the progress of human justice seemed to demand that those who engaged in the violence of war or armed conflict had to observe evolving common standards of humanity if any semblance of a return to peace was to endure after the violent combat ended and in the interests of a sustainable peace. One of the earliest recorded trials and punishments in Europe, meted out by a local tribunal constituted by representatives of the Holy Roman Empire for crimes committed during the occupation of the town of Breisach, was that 
of Peter von Hagenbach; he was executed on conviction of war crimes in 1474. The trial and punishment, while significant, may also have been used to cover the responsibility of von Hagenbach's superior, the Duke of Burgundy, whose orders he was following.

In the context of more recent history, it should not be forgotten that the ICC is a creation of international law, which itself is a product of the desire of humanity to link the desire for peace and security with universal concepts of justice.

One of the earliest architects of international law, Hugo Grotius, in the early part of the 17th century linked the right of states to use violence only for defensive purposes and the notion that those who waged war with illegal or wrongful intent would have to be held accountable for their actions. At the earliest stages of the formulation of international law, Grotius was already focusing on the need for justice to accompany the ending of war:

Furthermore, according to the principles which in general terms we have elsewhere set forth, those persons are bound to make restitution who have brought about the war, either by the exercise of their power, or through their advice. Their accountability concerns all those things, of course, which ordinarily follow in the train of war; and even unusual things, if they have ordered or advised any such thing, or have failed to prevent it when they might have done so.

Thus also generals are responsible for the things which have been done while they were in command; and all the soldiers that have participated in some common act, as the burning of a city, are responsible for the total damage. In the case of separate acts each is responsible for the loss of which he as the sole cause, or at any rate, was one of the causes...

The driving force of a major part of international law right up to the early part of the 20th century was to develop processes such as bilateral and multilateral treaty negotiations and organizations to limit the illegal use of force by states and ensure that judicial mechanisms could settle disputes that could trigger wars and other violent conflicts. It is not an accident of history that the place of many of these developments seem to end up at the European countries of the Netherlands and Switzerland and particularly the cities of The Hague, the present site of the ICC, and Geneva, the city that gives its name to the laws of war.

The Swiss architects of the modern laws on war crimes and crimes against humanity, Gustave Moynier and Henri Dunant, saw the horrifying impact of battles on the dying and the wounded during the Napoleonic wars, especially at the battle of Solferino. They pressed for rules to limit the brutality of the battlefield and for basic rules of humanity for the wounded and non-combatants. After founding what eventually became the International Committee of the Red Cross, the two humanitarians were successful in getting the Swiss govern- 
ment to convene negotiations on the laws of war that would eventually become the Geneva Conventions of 1864. The purpose of these earliest international rules, which put limits on what was permissible in situations of war, included the humane treatment of sick, wounded or out-of-combat soldiers and allowed unimpeded access to medical aid provided by neutral organizations such as the Red Cross. Moynier sought to have a convention drafted for an international criminal court to prosecute breaches of the Geneva Conventions but was not successful. That would have to wait for another century and more events to happen to trigger the establishment of a permanent court.

In the 19th century, President Abraham Lincoln commissioned international law jurist Francis Lieber to draft the military code for the Union Army regarding rules of war concerning prisoners of war, the wounded and civilians under occupation. If ever there was a leader who realized that justice both ad bellum and in bello was required to promote a sustainable peace after the conflict "with malice to none and charity for all" it was President Lincoln.

The Hague Conventions of 1899 and 1907 were a turning point in the move to establish positive laws of armed conflict in the form of an international treaty. The Conventions drew and expanded on the earlier Geneva Conventions and the Lieber Code to create the first substantial body of laws of war and armed conflict. Acknowledging the growing plight of civilians in such conflicts, the Hague Conventions established some of the first major provisions dealing with the protection of civilians in regulations annexed to the Conventions while stating in the preamble: "the inhabitants and the belligerents remain under the protection and rule of the principles of the law of nations, as they result from the usages established among civilized peoples, from the laws of humanity, and the dictates of the public conscience." This famous statement, known as the Martens Clause, recognizes the possibility of a common human understanding of what is required by the public conscience of nations during armed conflicts, the satisfaction of which is a sine qua non of any notion of sustainable peace in the aftermath of war.

The Hague Conventions' major weakness was that they imposed obligations only on states and did not pretend to extend criminal accountability to individual transgressors of the provisions of the Conventions. However, the Hague Conventions did establish in the modern era that a body of international law, called humanitarian law, dealing with the laws of war and crimes of war would be a common standard for all nations. The future would foretell that repudiation of such common standards of humanity would result in the bloodiest century of modern history.

At these earliest attempts to codify the common standards of humanity in armed conflict, there was an acknowledgment that a lack of accountability for violations of these common standards would hinder the prospect of a durable peace. In the view of one writer, the failure of the 1899 and 1907 Hague Peace 
Conferences to achieve peace with justice brought on the horrors of World War I.

In 1915, the World War I Allies announced that the Turkish slaughter of the Armenian population was a new crime against humanity and civilization, a crime for which all members of the Ottoman government and their agents would be held responsible. However, the Allies did not follow through on the need to enforce the newly established norm of crime against humanity and the threatened prosecutions of the Turkish government representatives in the 1920 Treaty of Sèvres did not materialize as Turkey did not ratify the treaty. Instead, the subsequent Treaty of Lausanne extended amnesties to the perpetrators of the newly established crimes against humanity.

This act of impunity by the Turkish government in the face of the newly established norm of crimes against humanity was noted by a future leader, one who would go on to instigate a global military conflict and commit the greatest mass slaughter in human history: Adolf Hitler. In justifying his decision to invade Poland on August 22, 1939, and send millions of men, women and children to their death "mercilessly and without compassion" in that country in order to create more "Lebensraum" [greater living space] for the German people, he uttered a sentence that should link indelibly the concepts of peace and justice in humanity's conscience: "Who, after all, speaks today of the annihilation of the Armenians?'P

Sadly, in the words of the German philosopher Hegel, one of the few things that the international community learns from history is that it does not learn from history. The inability to follow through on those charged with war crimes, including the emerging concept of responsibility for wars of aggression, was repeated at the end of World War I when the victorious Allies proposed to try Kaiser Wilhem II for "a supreme offence against international morality and the sanctity of treaties," refused to extradite him; the Kaiser had taken refuge there. However, the 1919 Treaty of Versailles did recognize the right of the Allies to try German military personnel for war crimes. Yet again, the political will seemed to be lacking and few trials of German soldiers occurred, with minimal sentences handed down. The failure to establish an effective justice process in the aftermath of the first global war could well have emboldened the leaders of the future Third Reich to instigate their slaughter of millions of civilians. The lesson of the early 20th century seems to be that the failure to follow through on justice imperils the prospect of peace in the future.

In the aftermath of the slaughter and genocidal horrors of World War II, the victorious Allies finally seemed to realize the importance of linking justice with the prospect of sustainable peace in the future. Some of the Allied leaders, including Churchill and the influential United States (US) Treasury Secretary Henry Morgenthau, had initially persuaded President Roosevelt to commit the 
antithesis of justice, namely the swift execution of the core Nazi leadership. However, there was a realization that a sustainable peace in Europe demanded holding the Nazi leaders accountable for their horrible crimes before an international tribunal of law. The US Secretary of War Henry Stimson argued against this form of victors' vengeance, pointing out the links between peace and justice:

We should always have in mind the necessity of punishing effectively enough to bring home to the German people the wrongdoing done in their name, and thus prevent similar conduct in the future, without depriving them of the hope of a future respected German community. (Those are the two alternatives.) Remember, this punishment is for the purpose of prevention and not for vengeance. An element in prevention is to secure in the person punished, the conviction of guilt. The trial and punishment should be as prompt as possible and in all cases care should be taken against making martyrs of the individuals punished.12

There was renewed determination in the Moscow Declaration of 1943 by the Allies that those who had initiated the war and had committed war crimes had to stand trial, regardless of where those crimes were committed.

In preparing the groundwork for the Nuremberg trials of the Nazi war criminals, the London Conference of August 1945, led by the four main Allied powers, incorporated the Hague Conventions, the still-born Kellogg-Briand Pact, which proposed the norm of crime against peace, and the crimes against humanity concept crystallized in the context of the Armenian genocide. The Tokyo tribunal that would try the Japanese war criminals also incorporated these earlier attempts to link justice with peace in the aftermath of the war in the Asia-Pacific.

The Agreement for the Prosecution and Punishment of Major War Criminals and the Charter of the International Military Tribunal was adopted on August 8, 1945. The Agreement and Charter established the criminal liability of those charged before the Nuremberg trials. The details of such criminal liability would foreshadow the definition of serious international crimes that would be listed as being within the jurisdiction of the future ICC: conspiracy to commit crimes against peace; planning, initiating and waging wars of aggression; war crimes; and crimes against humanity. Again, foreshadowing the modus operandi of the ICC, the focus of the indictments was not aimed at lower-level German military personnel, but at 24 individuals who gave birth to the title of their trial, namely the Trial of the Major War Criminals. After a long and historic hearing that lasted almost a year, the Tribunal handed down 12 death sentences and convicted 19 other major Nazi leaders. The trials of thousands of Nazi officials of lesser rank continued in Germany and elsewhere, reaching its zenith in the abduction, trial and conviction of Adolf Eichmann in Israel on December 11, 1961. 
While the Nuremberg trials were criticized for being a form of victor's retribution or vengeance, the demands and foundations of justice recognized by human civilization over the centuries required that there be an accounting for the atrocities committed by the major Nazi leaders. Indeed, the criminal liability of crimes against humanity was a recognition that past criminal atrocities, such as the Armenian genocide, could not go unpunished if future similar actions were to be deterred. The fact that the impunity of those who had orchestrated the Armenian genocide was used by Adolf Hitler to justify the Holocaust is conclusive proof of this requirement to hold perpetrators of crimes against humanity accountable.

The Nuremberg trials were followed widely in Germany and throughout the world. While Germans may have been more comfortable with a German court trying the top leadership of the National Socialist regime, the imperatives of a sustainable peace in Europe required that the population face the horror that was committed in their name and willingly cooperate in the post-war effort to purge the country of the Nazi philosophy that had led to the most gruesome atrocities humanity had ever experienced.

One basis of criminal liability was still waiting to be established: the crime of genocide. Although the Nuremberg Prosecutor used the term "genocide" to charge the major Nazi war criminals, this ground of criminal liability was yet to be established. The origins of that criminal liability had been proposed since the 1930s with the tireless work of Polish lawyer Rafael Lemkin. He was so appalled by the horror of the Armenian genocide, the killing of the Iraq Arameans in the 1930s, and finally the Holocaust, that he began his life's work to establish the crime of attempts to wipe out, in whole or in part, an entire group of people, which he termed genocide. His campaign was finally successful when on December 9, 1948, the United Nations (UN) General Assembly passed the Convention on the Prevention and Punishment of the Crime of Genocide. The Genocide Convention entered into force on January 12, 1951. The historic definition of genocide in article II of the Genocide Convention would reverberate down the years and find the same definition substantially unchanged in article 6 of the Statute of the International Criminal Court ("ICC Statute").

While the Genocide Convention called for the establishment of a permanent international crime of genocide, it lacked the essential feature of enforcement through an independent tribunal that could attach criminal liability to individuals in the manner that future ad hoc international criminal tribunals and the ICC could accomplish. Instead, the Genocide Convention provided only that prosecution of this most serious of international crimes would proceed either at the national or international level before a penal tribunal whose jurisdiction contracting parties had agreed to. There had been a proposal to establish a court to hear allegations of genocide in earlier drafts of the Genocide Convention, 
but as with those who opposed the creation of the ICC, some of the members of the international community argued that the time was not ripe for such an institution.

\section{THE CAMPAIGN FOR JUSTICE, BEFORE AND AFTER THE COLD WAR}

The fleshing out of the details of any such future tribunal would be left to the International Law Commission (ILC), which had also just been established. In the 1950s, both the ILC and the UN General Assembly were the prime movers on the establishment of draft codes of international crimes and started work on the drafting of the statue of an international criminal court. However, the Cold War placed severe ideological barriers to progress on both fronts and the impact of the condoning of such international crimes was felt by the peoples of East Timor and many other fronts where the Cold War raged.

The history of the Cold War is replete with evidence that justice is not a dispensable option to sustainable peace, either in a country, a region or indeed for the entire international community.

From the genocides in Cambodia and East Timor to the slaughter of civilians in Indonesia, South and Central America, and the Soviet Union, the prevalence of impunity for serious international crimes extended around the world and to both sides of the Cold War. The failure of the UN Security Council and its permanent members to either prevent or stop unfolding genocides and mass slaughter, such as the one that killed up to a third of the population in East Timor, would register in the minds of many of the drafters and supporters of the ICC Statute in Rome in 1999.

One casualty of the Cold War was the efforts by the ILC to draft and establish a permanent international criminal court. The ILC had submitted drafts of the statute of such a court along with a draft code of offences. However, the $\mathrm{UN}$ and its member states had moved the international justice agenda to the side in the face of opposing ideological camps. . $^{3}$

With the end of the Cold War, it is an irony of international justice history that it was the fear of the exploding global narcotics trafficking, rather than exploding impunity, that triggered the move by the international community and the international human rights movement to establish the ICC. In 1989 the twin Caribbean states of Trinidad and Tobago were successful in getting the UN General Assembly to pass a resolution requesting the ILC to again take up the task of considering the establishment of an international criminal court that could deal with drug trafficking, along with its ongoing work on a draft code of international crimes.

By 1994 the ILC had completed the task of developing the main procedural and organizational structure of the Court but would not complete the task of 
drafting the "Code of Crimes Against the Peace and Security of Mankind" until 1996. These documents would become the foundations of both the ad hoc Tribunals for Yugoslavia and Rwanda and later the ICC.

The history and legacy of the International Criminal Tribunal for the former Yugoslavia (ICTY) is, in many respects, the catalyst for both a local and a global thirst for justice in the aftermath of the demise of the Cold War and the guilt arising out of the failure of the UN and the major powers in the Security Council to live up to the promise of "never again."

Yugoslavia, a country of historically warring ethnic groups, was one of the first casualties of the failure of the US and other major powers to establish a new global order of peace and security with the fall of the Soviet Union. With the death of Marshal Tito, aspiring Serbian leaders would ignore the basic standards of humanity and use the disintegration of the multiethnic state to gain territorial and political power at any cost.

In the immediate aftermath of the declaration of independence by Bosnia in March of 1992, President Slobodan Milosevic of the Federal Republic of Yugoslavia and his army, together with the Bosnian Serbs led by the soonto-be indicted war criminals Radovan Karadžić and General Ratko Mladić, initiated a savagery unmatched since World War II. The atrocities reached their zenith in the siege of Sarajevo and the massacre at Srebrenica, which shocked the conscience of the world but saw little action from the UN Security Council or the assembled economic and military might of Europe.

The UN Commission of Experts' report on the war crimes in Bosnia revealed the horrific details of what would soon be judged in individual cases to be war crimes, crimes against humanity, and, regarding Milosevic, the ultimate crime of genocide.14 He would die before judgment was passed on his crimes. Over 200,000 people would perish before the Dayton Peace Accord ended the war.

The UN Commission of Experts on Bosnia warned that preventing such crimes are as much a moral cause as a military cause, which demands that the international community ensure such horrors do not reoccur and strongly proposed the establishment of an international tribunal to hold the main perpetrators of these crimes accountable:

The United Nations experience in Bosnia was one of the most difficult and painful in our history. It is with the deepest regret and remorse that we have reviewed our own actions and the decisions in the face of the assault on Srebrenica. Through error, misjudgment and an inability to recognize the scope of evil confronting us, we failed to do our part to help save the people of Srebrenica from the Serb campaign of mass murder .... Srebrenica crystallized a truth understood only too late by the United Nations and the world at large: that Bosnia was as much a moral cause as a military conflict. The tragedy of Srebrenica will haunt our history forever.

In the end the only meaningful and lasting amends we can make to the citizens of Bosnia and Herzegovina who put their faith in the international community is to do 
our utmost not to allow such horrors to recur. When the international community makes a solemn promise to safeguard and protect innocent civilians from massacre, then it must be willing to back its promise with the necessary means.

The UN Secretary-General Kofi Annan agreed with the Commission Report and in November of 1999 apologized for the UN's failing in Bosnia. The Security Council decided on February 22, 1993, to agree with the recommendations of the Commission and called for the establishment of a criminal tribunal to prosecute "persons responsible for the serious violations of international humanitarian law committed in the territory of the former Yugoslavia since 1991.'18

In a subsequent Security Council resolution, the Statute of the International Criminal Tribunal for the Former Yugoslavia was adopted on May 8, 1993.17 The Statute was to apply the customary international law rules of humanitarian law and its territorial jurisdiction would be limited to the former Yugoslavia. The Court could prosecute for international crimes that started in 1991. There was an unspoken consensus in the Security Council and the international community that, without the main organizers and perpetrators of the conflict in the disintegrating Yugoslavia being held to account, the prospect for an enduring stability in the Balkans would be greatly diminished.

Sadly, the consensus to hold those accountable for the gravest of international crimes only after the international community had so abjectly failed to stop it in the first place would be repeated in Rwanda. The Report of the Independent Inquiry into the actions of the UN during the 1994 genocide in Rwanda produced similar views, stating categorically that "[t]he United Nations failed the people of Rwanda during the genocide in 1994.' The report urged far more effective genocide prevention strategies, which included the obligation under the Genocide Convention to "prevent and punish" genocide.

Given these two independent reports, it is hard to fathom those who argue that in the interests of peace, whether temporary or not, those who perpetrate the worst crimes known to humanity should not be held accountable.

Rwanda itself requested the Security Council to establish the second ad hoc international criminal tribunal for the genocide by the previous Hutu government and its militias. In November 1994 the Security Council acceded to the request and created the International Criminal Tribunal for Rwanda (ICTR) for the prosecution of genocide and other serious violations of international humanitarian law committed in Rwanda and neighbouring countries. If

The legacy of both Tribunals, but more substantially the ICTY, is of very progressive approaches to the interpretation of international humanitarian law and human rights law that have transcended the principles of the Nuremberg trials. The most important progressive interpretation by the ICTY is that crimes against humanity can be committed outside international conflicts, 
war crimes can be committed during internal conflicts, and those who have organized, perpetrated, and aided and abetted these crimes can and will be held accountable. While some have argued that the Tribunals appeared to be motivated by the guilt of the international community for failing to stop the mass slaughter in the Balkans and Rwanda, both were regarded as essential to the restoration of peace and security.

The UN Security Council, in setting up the ICTY, stated that even with the ongoing crimes constituting a threat to international peace and security, the Tribunal would assist in putting an end to such criminality and "contribute to the restoration and maintenance of peace" and security.?

The ICTY itself make the link between peace and justice in the following manner:

The key objective of the ICTY is to try those individuals most responsible for appalling acts such as murder, torture, rape, enslavement, destruction of property and other crimes listed in the Tribunal's Statute. By bringing perpetrators to trial, the ICTY aims to deter future crimes and render justice to thousands of victims and their families, thus contributing to a lasting peace in the former Yugoslavia.

Likewise, the Security Council in establishing the ICTR asserted that prosecuting those responsible for serious violations of international humanitarian law would "contribute to the process of national reconciliation.'2 The ICTR also claimed it would "contribute to the process of national reconciliation in Rwanda and to the maintenance of peace in Rwanda and the region.' 3

The Security Council linkage of the violation of humanitarian law norms with a threat to the peace to establish the Tribunals under its powerful Chapter VII powers was also laying the ground for further global initiatives to establish more effective international responses to such violations. . $^{4}$ That more effective global response would come in the determination by a majority of the world's states to establish a permanent international criminal court in the summer of 1998.

However, it was clear that the two Tribunals were designed only for designated territories and specific allegations of gross impunity and could not be a substitute for a permanent criminal court given ongoing allegations of gross impunity around the world.

Some of the experts who have studied the establishment and legacy of the ICTY and ICTR are convinced that the ICC would not have been created without the two previous ad hoc Tribunals. Particularly, there is a claim that an extraordinary transformation in world opinion occurred largely because of the ICTY's operations. There is also a claim that the ICC has learned from both the successes and the failures of the ad hoc Tribunals in terms of both 
procedure and substantive legal issues, including the definition of the crimes codified in the ICC Statute. F $^{2}$

The legacy of the ICTY and ICTR ad hoc Tribunals also provide a history lesson. Prosecutions of those most responsible for serious crimes can lead to their marginalization, which itself could be a critical factor in peace negotiations and ultimate stability in the situation of conflict. Human Rights Watch has given a compelling account of how the indictment of Radovan Karadžić by the ICTY in the context of the Bosnian conflict led to his marginalization and prevented him from being a participant (and perhaps a spoiler) in the Dayton peace talks that ended the Bosnian conflict.

Likewise, the arrest warrant for Charles Taylor, the sitting Liberian President, at the start of the peace talks was also viewed as being conducive to the negotiations to end the conflict by "delegitimizing" Taylor domestically and internationally. This may well have led to forcing him to leave office and the country a few months later.

Perhaps the legacy of the ICTY and the ICTR, like Nuremberg, is the creation of a detailed historical record through evidence presented at fair and neutral trials. As in the case of the Nuremberg trials, the evidence of the atrocities committed in the former Yugoslavia and Rwanda can act as a bulwark against revisionism used by future unscrupulous leaders who deny past serious crimes and assert imagined humiliations to revive inter-communal conflict and human rights abuses. ${ }^{2}$ The ICTY database in The Hague reportedly has more than 9 million pages which can be accessed by prosecutors in the region; some of this collected evidence has been used in domestic prosecutions in Bosnia.

On December 21, 2017, the ICTY marked the end of its 24 years as an international criminal tribunal with its official closure at The Hague. Its record stands as a historic milestone for the progress of international criminal justice, with the indictments of 161 persons, of which 90 were found guilty and sentenced, including the two main architects of the atrocities in the Balkans, Radovan Karadžić and more recently Ratko Mladić, who was sentenced to life imprisonment on November 22, 2017. These two convicted international criminals are appealing their sentences before the residual Mechanism for the International Criminal Tribunals. It may have taken too long to first arrest them due to Serbia's complicity, but their final trial and sentencing demonstrates justice can be patient, seeking to establish the record of the fight against impunity. That record included over 10,800 trial days, 4,650 witnesses and about 2.5 million pages of transcripts and evidence 3

The success, partial or otherwise, of the ICTY and the ICTR has spawned other non-permanent hybrid international tribunals that seek justice with the peace that was established, sometimes long after the conflict has ended.

The Special Court for Sierra Leone (SCSL) was a hybrid tribunal set up jointly by the government of Sierra Leone and the UN under Security Council 
Resolution 1315. It was given a mandate to prosecute those with the greatest responsibility for serious violations not only of international humanitarian law, but also of the law of Sierra Leone, committed by various rebels and the army in the territory of the country since November 30, 1996.

As with other conflict situations in Africa, the civilian population of Sierra Leone suffered some of the most savage atrocities that humanity has witnessed during the 11-year civil war that started in 1991. Many of the atrocities were driven by the push to control the highly profitable trade in what have come to be known as "blood diamonds." Thousands of civilians were abducted and used as slave labour in the mining of diamonds, with accompanying widespread mutilation of limbs as an instrument of terror. Thousands more were killed in militia attacks, some burned alive in their homes after extensive looting of civilian property. There was also widespread enslavement of children under 15 as child soldiers and approximately 275,000 women and girls were victims of mass and systemic sexual violence and forced to become "bush wives" of the militia members.

The Trial and Appeals Chamber judges of the SCSL were jointly appointed by the government of Sierra Leone and the UN, with the international judges forming the majority in both chambers. While this hybrid Tribunal has attempted to integrate the presence of domestic judges into the work of the Tribunal, it is still regarded in international law as an international court independent from the domestic legal system of Sierra Leone. This Tribunal moved with relative speed and managed to prosecute two cases successfully before it completed its mandate. One case, completed on June 20, 2007, resulted in three accused from the Armed Forces Revolutionary Council receiving between 45- and 50-year sentences. The other case, completed on August 2, 2007, involved two accused individuals from the Civil Defence Forces receiving sentences of 15 and 20 years. The Court also had to deal with the Charles Taylor prosecution, the first former African Head of State to be indicted for serious violations of the relevant laws described above. For security reasons, his prosecution was moved to The Hague although still under the jurisdiction of the SCSL. Although the hearing of evidence started late on January 7, 2008, the case for the prosecution ended after hearing evidence from 91 witnesses.

On April 26, 2012, Charles Taylor became the first former Head of State since Nuremberg to be convicted of war crimes or crimes against humanity by an ad hoc tribunal. On October 10, 2013, Taylor was sentenced to 50 years imprisonment, to be served in a British jail.

The conviction was handed down more than a decade after Taylor aided and abetted rebels or the Revolutionary United Front (RUF) and Armed Forces Revolutionary Council in Sierra Leone to kill, rape and mutilate thousands of men, women and children. Taylor's trial and the issuance of a judgment in a credible judicial process send a strong signal that the world has become a less 
hospitable place for the highest-level leaders who are accused of committing serious crimes in violation of international law.

The remaining prosecution case concerns a fugitive, Johnny Paul Koroma. He went into hiding and was never arrested. On June 1, 2003, Koroma was officially declared dead in neighbouring Liberia under suspicious circumstances, but the indictment against him remains in force. In total, ten prosecutions were initiated. Two of the indicted RUF's brutal leaders, Foday Sankoh and Sam Brockarie, died before the trial, while one person, Samuel Norman, died during the trial. There were nine convictions in total, with sentences of between 15 to 52 years imposed, and eight of the convicted serving their sentences in Rwanda due to security challenges. The UN and the Sierra Leone government established the Residual Special Court for Sierra Leone to deal with witness protection, supervision of the prison sentences, and the Court records after the SCSL closed it operations in 2013.

The other ad hoc hybrid tribunals set up by the government of Cambodia and the UN and East Timor mixed Panels has so far proved much less effective. Regarding the Cambodia Tribunal, the refusal of the Cambodian government, and especially its authoritarian Prime Minister Hun Sen, with his own checkered past, to accept a truly independent international tribunal has led to a weak hybrid tribunal composed of a tribunal under Cambodian law controlled to a large extent by Cambodian judges and prosecutors, with international judges and prosecutors attempting to ensure international credibility. The Cambodian Tribunal is part of special chambers of the Cambodian court system called the Extraordinary Chambers in the Courts of Cambodia (ECCC). The Cambodian National Assembly approved the law establishing the ECCC on January 2, 2001, and started its operations in 2006. The subject matter jurisdiction covers genocide, crimes against humanity, grave breaches of the Geneva Conventions, and various violations of the 1954 Hague Convention and the 1961 Vienna Convention on Diplomatic Relations. Homicide, torture and religious persecution can also be prosecuted under Cambodian law; however, only homicide has been charged in two cases at the pre-trial stage. The prosecutions are limited to the most senior leaders of then Democratic Kampuchea who were most responsible for the genocide and atrocities committed during the 1975-79 period. ${ }^{3}$ After 30 years, at the time of writing only three Khmer Rouge leaders had been convicted of some of the worst atrocities since the Holocaust in World War II because of the decades of attempts to block accountability for the crimes committed by both China and the US. Cases against three other individuals are currently in the pre-trial stage.

The Tribunal began on February 17, 2009, with its first trial of Kaing Gech Eav (Duch), one of the five Khmer Rouge leaders being tried as the leaders most responsible for the deaths of up to 2 million people. Duch, the commander of the infamous torture and execution centre S21 in Phnom Penh, is 
one of five former Khmer Rouge leaders currently facing prosecution before the ECCC. However, serious allegations of political interference, low professional standards, and corruption have dogged the Court since its establishment in 2001. 3 On July 26, 2010, Duch was found guilty by the Tribunal after an eight-month trial. He admitted responsibility for the crimes committed while presiding over the Tuol Sleg prison, where about 14,000 individuals were tortured and killed during the Khmer Rouge's brutal rule. Duch was sentenced to 35 years in prison following his conviction for crimes against humanity and war crimes, with five years being deducted for his detention by the military before his transfer to the ECCC in 2007.

In addition to the corruption and politicization and the lengthy delays, the Court proceedings were halted by a long strike by its staff and withdrawal of funding. The UN restored funding in 2014 but there had been much cynicism and concern over a tribunal that had managed only one conviction at a cost of over \$300 million. Such criticism may have stirred more action at the Court. In November 2016 the Court upheld life sentences for two former Khmer Rouge leaders for crimes against humanity, even while they face a second trial for genocide and other crimes. Nuon Chea, aged 90, and ex-Head of State Khieu Samphan, aged 85, were first convicted in August 2014 of the forced evacuation of millions from the capital Phnom Penh into labour camps and the execution of hundreds of soldiers. Their appeal was unsuccessful although the hybrid Tribunal acknowledged errors were made at the trial. Many key leaders implicated in the Cambodian genocide had died of old age and disease without facing prosecution, including the most senior leader, Pol Pot, who died in 1998. In February 2017 charges were dropped against another Khmer Rouge official, Im Chaem, aged 74, who was accused of leading a labour camp in which tens of thousands of people died.

The Court's legacy and credibility will be further compromised if no additional trials are started, in part due to pressure from Prime Minister Hun Sen. This leader, a former member of the Khmer Rouge himself, has warned against other prosecutions, suggesting that they could lead to civil war. Sen's government has impeded access to potential witnesses, protecting those that have influence within the Sen government. The challenges faced by the ECCC illustrate the need for a permanent international court, free of political interference.

The East Timor situation is just as troubling as that of Cambodia. After the killing and destruction by Indonesian-led forces and militias that followed the UN-sponsored referendum in 1999, the UN Transitional Administration of East Timor established in 2000 special mixed international/East Timorese judicial Panels within the Dili District Court to prosecute those who had allegedly committed serious criminal offences that also constituted violations of international humanitarian law. There was great concern about the viability 
and effectiveness of these Panels, even though approximately 21 individuals were convicted with sentences ranging from four to 34 years' imprisonment. The criticism includes the postponement of scheduled hearings due to the unavailability of the judges and some appeals not being heard because the judges had not been appointed. 3 After East Timor became independent in May 2002, the Panels were transferred to the supervision of the government. However, when the continuing trials fell short of international standards, the UN withdrew its support for the Panels and they suspended operations permanently.t4

The demands of justice require not only the true independence of any international or hybrid criminal tribunal to prosecute the most serious of international crimes, but also the external guarantees that ensure the tribunal can meet its mandate of ensuring that such crimes do not go unpunished and to act as a catalyst for peace in the future.

All these ad hoc international criminal tribunals will end. Even the ICTY and the ICTR are being phased out. The Mechanism for International Criminal Tribunals has taken over several functions of both Tribunals, including appeals from the ICTR in 2012 and from the ICTY in 2013.

None of these tribunals were meant to be permanent. When they ended there was a vacuum which could only be filled by a permanent international criminal tribunal like the ICC or a new mandate from a regional human rights court that would focus primarily on the most serious international crimes listed in the ICC Statute. If the ICC did not exist it would have to be invented as it will likely be the "only game in town."

\section{THE BIRTH OF THE INTERNATIONAL CRIMINAL COURT}

While the ad hoc tribunals were being established and started operations, the UN General Assembly renewed its work to establish a permanent criminal tribunal that would not be limited to a defined territory. An Ad Hoc Committee of the Assembly would start with the draft statue of such a permanent court produced by the ILC. However, the political nature of the Ad Hoc Committee soon manifested itself, and some members even questioned the viability of such a permanent court. As the work went on, it became clear that the ILC's desire to have a permanent court that would have primacy over national courts in the case of grave international crimes would give way to the Ad Hoc Committee's desire to give primacy to national courts to prosecute such crimes and that a permanent court would only have "complementarity" jurisdiction if the national courts were unable or unwilling to genuinely prosecute such crimes. 17 This would become a crucial provision of the ICC, which should be a major counter-argument to those who would suggest that the ICC promotes 
a western and colonial approach to international humanitarian law and human rights.

In a similar fashion, and with a similar legacy, the Ad Hoc Committee insisted that the permanent court's jurisdiction would be limited by a detailed statute that would define the crimes that would be the subject of prosecution by the ICC. In addition, the Committee insisted on a listing of general principles of law and other substantive and procedural parameters within which the ICC would have to operate. The fear and uncertainty about too much judicial discretion was a motivating force for this UN Committee.

In contrast to the much less defined parameters of the ad hoc Tribunals for the former Yugoslavia and Rwanda, these detailed provisions insisted on by the Ad Hoc Committee and later agreed upon at the Rome Conference that established the ICC would have, in the view of this author, the effect of "constitutionalizing" the law relating to the most grave of international crimes together with the applicable general principles of law, including human rights norms. Following the bureaucratic nature of the UN, the General Assembly decided in 1996 to submit the work of the Ad Hoc Committee to lengthy sessions of a "Preparatory Committee" that involved member states, non-governmental organizations (NGOs), and international organizations in multi-week sessions that ultimately produced a final draft, the "Zuphen draft," to the Rome Diplomatic Conference in 1998.42

What took place at the Diplomatic Conference in Rome, which started on June 15, 1998, is a testament to the success of the global human rights and humanitarian movements linking up with a progressive group of nations called the "like-minded caucus" to produce a milestone in human progress, namely the establishment of the ICC. However, among the 160 state delegations and the hundreds of NGOs at the Rome Conference, a historic battle was shaping up between those states that wanted state sovereignty to trump the imperatives of fighting impunity, and those that wanted the world to see a new stage in the development of the rule of law in global affairs.

The former group, led by the US with strong support from China, India and Israel, wanted the permanent court to be subject to a Security Council veto on prosecutions. In addition, these countries wanted to eliminate the power of an independent prosecutor of the new court to start an investigation on his own initiative, called the proprio motu jurisdiction. The like-minded caucus of states, led by Canada and backed by an army of civil society groups and NGOs, refused to concede on these issues. Special mention must be made of the very powerful and effective lobbying strategies of the Coalition for the International Criminal Court (CICC), which is led and convened by Executive Director William Pace. Presently comprising approximately 2,500 organizations around the world, including leading human rights organizations such as Amnesty International and Human Rights Watch, the CICC has since 1955 
been the main force of global civil society in lobbying for the establishment of the Court. With the establishment of the ICC's Statute, the CICC has worked tirelessly to strengthen international cooperation with the Court and ensure its effectiveness and independence, while promoting stronger national laws that advance the complementarity nature of the Statute. The CICC has been involved in every stage of the development of the Court, from working in the Preparatory Committee leading to the Statute, to active participation in the annual Assembly of States Parties meetings.

The like-minded group of states led by Canada together with their civil society partners won the day, in no small measure due to the great diplomatic skill of Canadian diplomat Phillipe Kirsch, who was elected president of the Rome Conference's Committee of the Whole. His Committee had the daunting task of dealing with and brokering solutions regarding the most contentious issues. On July 17, 1998, the Statute of the International Criminal Court (also known as the Rome Statute) was adopted at the Rome Conference, with 120 states voting in favour, 21 abstentions, and without a formal roll call; only the US, China and Israel declared that they were opposed to the adoption of the ICC Statute. The Rome Conference also called upon the UN General Assembly to initiate another Preparatory Commission to draft the Elements of Crime and the Rules of Procedure and Evidence which would give further definitions to the crimes listed in the ICC Statute.

Negotiations at the Rome Conference tried hard to get the US onside. Before the Rome Conference, the Clinton administration supported a permanent international criminal court if the right protections for its military personnel were built into the court's statute. Indeed, the US had been the catalyst for the establishment of the ad hoc Tribunals for the former Yugoslavia and Rwanda. Some of the leading US experts had convincingly argued that the lessons learned from these Tribunals, despite their lack of resources, had shown how crucial criminal indictments and arrest warrants could be to combat impunity by isolating individuals responsible for these crimes, strengthening the hands of domestic rivals, and triggering international political will to take aggressive action to bring about the end of the conflict. ${ }^{3}$ Such views had been confirmed by the removal of President Slobodan Milosevic, the leader of the former Yugoslavia who had triggered the mass slaughter in the Balkans on June 28, 2001, to stand trial for genocide, crimes against humanity, and war crimes at the ICTY in The Hague. This was an historic first time that a former Head of State had been brought before an international criminal tribunal.

There is irony in the fact that the US had pressured strongly for an international criminal court that would be controlled by the UN Security Council, including eliminating the power of an independent prosecutor to start an investigation proprio motu. The UN Security Council was the same body that the US ignored in the decision to take military action in Kosovo to end the 
slaughter there. To dispel criticisms of its contrary positions, the US justified its position at the Rome Conference by asserting that, as the lone superpower, it would have the greatest burden of intervening in humanitarian crises and this would potentially open its military personnel to investigation by an independent prosecutor and the jurisdiction of the court. The like-minded caucus that led the opposition to this position has suggested that the US position was dictated more by the US Pentagon than the State Department and arose from the mistrust by the US military of the decision of the International Court of Justice (ICJ) in Nicaragua $v$ United States, ${ }^{+5}$ which resulted in the withdrawal of compulsory jurisdiction of the ICJ.

When the actual provisions of the ICC Statute are examined, it is clear the US had little to be concerned about. Some would argue that most of the Pentagon's concerns had been addressed in the detailed provisions of the Statute. This included the fundamental principle of complementarity, which required the primacy of national courts' jurisdiction over the crimes listed in the Statute. Only if the US courts were "unable or unwilling" to prosecute any alleged offences listed in the ICC Statute would the jurisdiction of the Court be triggered. Af Likewise, the Rome Conference had decided to curtail the ability of the Chief Prosecutor to overreach his proprio motu powers of investigation by imposing the supervision of the Trial Chamber of the Court over these independent powers. The omission of the US from the majority of states supporting the introduction of a global order against impunity was a sad historic event. This was the same superpower that had shown the greatest leadership in the Nuremberg and Tokyo war crimes tribunals, the Universal Declaration of Human Rights, and the establishment of the two ad hoc Tribunals for the former Yugoslavia and Rwanda. But the challenge for the ICC was just beginning with the election of George W. Bush and his administration, who would be ferocious opponents of the newly established ICC. A7

The Statute came into force on July 1, 2002, when it received its 60th ratification. The pace of ratifications was substantially faster than had been expected. This result was even more significant than first may be apparent. While even states that had opposed the Statute, including the US and Israel, signed on just before the deadline of December 31, 2000, those wishing to ratify after signing had to take very significant legislative and administrative steps in their own jurisdictions to comply with the obligations of being parties to the ICC Statute.

In a relatively very short space of time, a number of these states (but many more still need to do so) passed legislation to ensure their own criminal laws were compatible with the ICC Statute, especially regarding the crimes of genocide, crimes against humanity, and war crimes, and to give their courts the ability to exercise universal jurisdiction over these crimes. Likewise, the ratifying states also had to provide for the necessary legislative and adminis- 
trative mechanisms for cooperation with the ICC over the investigation, arrest and transfer of alleged criminals targeted by the Chief Prosecutor of the ICC. As of August 1, 2017, 123 states - a majority of states in the world-have signed and ratified the ICC Statute. Africa, with 34 State Parties, accounts for the largest number of State Parties, with 25 from Western Europe and other states, 28 from Latin America and the Caribbean, 19 from Asia-Pacific states and 18 from Eastern Europe.

The rapid legislative and administrative changes in many of the 123 states that have presently ratified the Statute could by themselves foster sustainable peace in their respective territories without the Court ever having started an investigation in any of these countries. However, there is great concern that of the present 123 State Parties, by June of 2014, most State Parties had still not passed the necessary legislation to implement the ICC Statute.

Greater numbers of State Parties implementing the ICC Statue will be needed to cement the argument that the ICC is an institution that promotes peace with justice as opposed to justice against peace. Nevertheless, the states that had ratified the ICC Statute accepted the challenge of creating the new global rule of international criminal law. In the early years of the Court, State Parties in the Assembly of State Parties assisted in formulating the ICC Elements of Crime and the Rules of Procedure and Evidence, together with the election of judges, the Registrar and the Chief Prosecutor of the Court.

The Assembly of States Parties is therefore a type of both legislative and oversight body of the ICC. Made up of all the ratifying states, the Assembly sessions are also open to NGOs and observer states. In addition to electing the above key positions in the Court and approving the budget of the ICC, the Assembly also provides oversight and guidance to the administration of the Court. A growing controversial role for the Assembly is also to consider referrals from the Court regarding non-cooperation by states. This role may well become the greatest challenge for the Assembly as the Court begins to urge State Parties to do more in ensuring that the arrest warrants issued by the Court are executed, especially the arrest warrant issued against the President of Sudan, Omar Al Bashir.

In the same period in which the States Parties were building the Court's basic rules and infrastructure, the Bush administration was focused on undermining the Court.

The Bush administration first indicated on May 6, 2002, that it would not become a party to the ICC Statute, thereby "unsigning" from the majority recognition of the need for a global rule of law against gross impunity for genocide, crimes against humanity, and war crimes. This unprecedented unsigning of its international legal obligations was followed by the Bush administration pressuring states receiving military and financial aid to sign bilateral agreements that would make US military officials and civilians immune from being 
subject to the ICC's jurisdiction. The Bush administration officials were proceeding under the view that article 98(2) of the ICC Statute permitted states to impede surrender of an accused if it would require a violation of its legal obligations to another state.

Just over 100 states succumbed to such geopolitical blackmail by the Bush administration by 2006, while 54 countries stood on their principles in the same period and refused to bend to the ideological campaign against the ICC by the Bush administration. Some of the poorest countries in Africa lost critically needed foreign aid funds, including Benin, Mali, Tanzania and Lesotho, for refusing to go along with the demand for article 98(2) agreements.

Only a handful of the ratifying states succumbed to this pressure, with key US allies such as Canada, Mexico and most Western European states leading the opposition to this attack on the ICC. The petulant attempts by the Bush administration continued with threats to veto UN Security Council resolutions on peacekeeping if the jurisdiction of the ICC over such operations were not ousted. The attempts to undermine the ICC reached absurd heights when President Bush on August 2, 2002, signed the American Service Members' Protection Act, which was nicknamed the "Hague Invasion Act." This astonishing work of Bush officials led by senior State Department official and later US Ambassador to the UN, John Bolton, now National Security Advisor to President Trump, prohibited US government agencies from cooperating with the ICC and included the authorization of the use of force to free any American national who was detained or imprisoned by the ICC. A

The fact that large numbers of the world's states were able to resist the attempts by the Bush administration to undermine the newly born ICC is a testament to the will of humanity not to retreat in the evolution of a global rule of law against gross impunity. Leading experts have asserted that the establishment of the Court is one of the most important developments in international law. It could contribute not only to the restoration of peace and reconciliation in specific situations, but also, in the words of Professor William Schabas, contributes to the evolution of a more peaceful global society:

The Influence of the Rome Statute will extend deep into domestic criminal law, enriching the jurisprudence of national courts and challenging prosecutors and judges to display greater zeal in the repression of serious violations of human rights. National courts have shown, in recent years, a growing enthusiasm for the use of international law materials in the application of their own laws. A phenomenon of judicial globalization is afoot. The Statute itself, and eventually the case law of the International Criminal Court, will no doubt contribute in this area.t9 


\section{THE STATUTE OF THE COURT; BALANCING NATIONAL SOVEREIGNTY; PEACE AND JUSTICE}

The desire to balance national sovereignty with justice led the drafters of the ICC Statute at Rome to impose a much more detailed set of provisions on the crimes within the jurisdiction of the Court and the rules of evidence and procedure in comparison to the ICTY and ICTR. This was partly a reaction to criticism that the ad hoc Tribunals had too much liberty to interpret and even modify the provisions relating to jurisdiction, procedure and evidence under which they operated. The imposition of such detailed rules upon the ICC was the subject of much heated discussion at the Rome Diplomatic Conference.

The provision in the ICC Statute that allows states almost complete leeway to pursue national reconciliation and peace through their own investigative, judicial and other similar institutions is the principle of complementarity.

The very definition of this concept can be found in the preamble to the ICC Statute. That preamble states that "the International Criminal Court established under this Statute shall be complementary to national criminal jurisdictions.' This concept that the ICC does not have supremacy over national courts is repeated in the very first article of the ICC Statute. So, while the preamble to the ICC Statute speaks with such eloquence of the common desire of humankind not to let the most serious of crimes go unpunished and that such crimes threaten the peace, security and well-being of the world, it also accepts that territorial integrity or political independence is a fundamental part of the purposes and principles of the UN. These principles must be balanced against the fight against impunity for the most serious crimes that shocked the conscience of humanity in the 20th century. What the preamble is stating in a circuitous fashion is that without a permanent institution dedicated to justice against impunity, the chances of a sustainable peace without mass atrocities as witnessed in the last century are greatly diminished.

Despite this primacy of national sovereignty and courts over the jurisdiction of the ICC, the US negotiators at the Rome Conference were not convinced that their military personnel could still avoid being hauled before the Court. Such a fear would almost be a fantastical admission that the much-lauded American justice system is not to be regarded as legitimate. This is because the ICC Statute balances national sovereignty and justice carefully by stating in article 17 that the Court can still have jurisdiction where the state is unwilling or unable genuinely to carry out its own investigations or prosecutions. This safeguard for justice ensures that impunity cannot hide behind illusory or non-existent national judicial institutions. 
National sovereignty and the ability to conduct genuine domestic investigative and judicial proceedings in civil conflicts are further reinforced by the detailed provisions on the ICC's jurisdiction over subject matter, territory and persons, the parameters around the independence of the Chief Prosecutor, the oversight of the Pre-Trial Chamber, and the role of the UN Security Council.

Turning to the jurisdiction of the Court over subject matter, the ICC Statute in article 5 also balances national sovereignty over justice by limiting the Court's jurisdiction to only the most serious crimes of concern to the international community as a whole. These are of such grave character that in many cases peace efforts have either failed or never been undertaken because the perpetrators have initiated the crimes as a sustained strategy to obtain or keep power. The crimes listed in article 5 are (a) genocide, (b) crimes against humanity, (c) war crimes, and (d) aggression. The first three crimes are defined in greater detail in articles 6 to 8 of the Statute and further elaborated in the Elements of Crime as drafted by the Assembly of State Parties. The Rome Conference resolved the contentious issue of the crime of aggression, demanded by the nations who had been colonized in the past, by leaving it to the Assembly of State Parties to define it, starting within seven years of the establishment of the Court. The Assembly of State Parties adopted the definition of Aggression at the Kampala Conference of 2010 and in December 2017 decided to activate the Court's jurisdiction over this crime as of 17 July 2018.

What we see in the provisions of the ICC Statute is the constitutionalization of the whole body of international criminal law, which, by itself, also incorporates the body of customary and treaty-based humanitarian law and international human rights law. While the ad hoc Tribunals had also prosecuted and interpreted customary international law on crimes against humanity, the ICC Statute consolidated over a century's worth of jurisprudence and customary law on the most serious of international crimes into a constitutionalized definition of these crimes, while also expanding their scope to cover gender crimes, including various forms of sexual violence, the criminalization of the enslavement of child soldiers, and attacking UN peacekeepers.

One writer, Sadat, has claimed that while the ICC Statute takes the form of a treaty, it has the status of a constitution. This view of the ICC Statute challenges the "Westphalian model" of international law, which is premised on the view that international law can only be prescribed by the consensual acts of states or other law-making bodies. This theory claims that the ICC Statute represents a "constitutional moment" in the development of international law but acknowledges that, while the ICC Statute was revolutionary, it is still primarily a treaty between consenting State Parties but with the ability of the UN Security Council to refer non-State Parties to the Court. It is this latter provision that reinforces the thesis that the ICC Statute moved away from the Westphalian model of international law. The ICC Statute was not an 
easy achievement given the opposition by powerful states such as the US and given that as a matter of law, institutional structure, and process, many of the prerogatives of sovereignty remain. 3 The foundation of this view of the constitutional nature of the ICC Statute is based on the view that the UN Charter is a form of "constitution" for the international community, which cannot be ignored by non-party states. The creation of the ICC is therefore part of the development of the UN system as it has been created through the efforts of UN bodies, including the Rome Conference.

The codification of the customary international humanitarian laws into the ICC Statute will, according to the view of the "constitutionalists" of which this author is one, lead to the judicial Chambers of the ICC interpreting the ICC Statute as they would a constitutional document. With the progress of cases heard by the ICC Chambers, over time the constitutional approach may lead to the expansion of the definition of crimes beyond that presently provided in customary international humanitarian law or human rights law.

Not surprisingly, there are strong critics of this constitutional view of the ICC Statute, especially from American jurists. Another writer, Gallant, suggests that the ICC is more a result of evolutionary prescriptive norms from various sources of international law, including the UN and the Assembly of States Parties of the ICC. Behind such opposition to the view of the ICC as a form of constitution for international criminal law is the refusal to accept that such a momentous event could have occurred without the consent of nine of the world's most powerful and populous countries, including the US, China and India.

It should be noted, however, that the US did sign the ICC Statute, but later the Bush administration took the unprecedented step of "unsigning" from the ICC Statute. The Obama administration lessened official American government opposition to the ICC and unofficially supported the operations of the Court. Given the nationalist "America First" approach of the Trump administration, there is likely to be less support for the Court, especially if there is any chance of an ICC investigation of possible American complicity in actions that are alleged to be serious crimes in Afghanistan involving the US military. This serious potential challenge to the Court is discussed in Chapter 6.

However, any Democratic administration in the US is unlikely to obtain the challenging two-thirds majority of the US Senate needed to ratify the accession of the US to the ICC Statute due to persistent opposition to the Court from the Republican Party.

The constitutional view of the ICC Statute may also be at odds with the specific provision of article 10, which states that "[n] othing in this Part shall be interpreted as limiting or prejudicing in any way existing or developing rules of international law for purposes other than this Statute.' ${ }^{\prime}$ While this provision would seem to prevent codification of previous customary international crimi- 
nal law in the ICC Statute, its main purpose is to allow for new developments that may not have been foreseen at the Rome Diplomatic Conference. As such, the ICC Statute has been amended to include the crime of aggression and to prohibit the use of certain weapons not already listed in article 8 of the Statute.

As far as the actual provisions in the Statute and the Elements of Crimes are concerned, there is little doubt that the Trial and Appeal Chambers of the ICC will treat them as a constitutionalized version of prior customary and treaty laws relating to the most serious international crimes. The practical effect of this constitutionalization could lead to the Chambers giving wider interpretations of prior customary and treaty law, in the same way that judiciaries around the world give liberal interpretations of entrenched constitutions to make them relevant to societal developments.

The definition of crimes against humanity in article 7 and expanded further in the Elements of Crime includes progressive interpretations of the ICTY regarding "gender crimes" as enumerated acts. These gender crimes can also constitute war crimes under article 8 of the ICC Statute. By entrenching such prior jurisprudence of the ad hoc Tribunals, the ICC Statute has become a constitutional document for this and other international crimes. The ICC Statute now spells out that crimes against humanity include not only the variations of murder, torture, enslavement, and deportations or forcible transfer of populations, but also detailed provisions relating to gender crimes. These include rape, sexual slavery, enforced prostitution, forced pregnancy, enforced sterilization or any other form of sexual violence of comparable gravity.

Regarding the definition of war crimes, here also the Statute takes into account the jurisprudence of the ad hoc Tribunals and codifies over a century of international treaty and customary laws dating back to ancient notions of jus in bello and the early codifications in the Hague Conventions of 1899. The three main categories that are extensively defined in the Statute and the Elements of Crime are: (a) grave breaches of the Geneva Conventions of 1949; (b) other serious violations of the laws and customs applicable in international armed conflict, within the established framework of international law, and followed by a very long list of such violations; and (c) in the case of armed conflict not of an international character, serious violations of article 3 of the Geneva Conventions of 1949 that focus on non-combatants, including those who have laid down their arms or are hors de combat through sickness, wounds, detention or any other cause.

One major aspect of the overlap between the constitutionalized provisions relating to international and internal conflicts is that the ICC Statute builds on the jurisprudence of the ad hoc Tribunals by issuing a warning of potential criminal prosecution to those who think that national sovereignty preserves 
impunity for war crimes. The ICC Statute thereby could well act as a proactive instrument of sustainable peace in troubled parts of the world.

The provisions in article 6 of the ICC Statute on the crime of genocide also draw on the provisions of the Genocide Convention and the jurisprudence of the ad hoc Tribunals. Regarded as the most serious of the international crimes and with its legacy of the Holocaust, the definition includes the requirement of specific intent or dolus specialis to destroy, in whole or in part, a national, ethnical, racial or religious group. The five enumerated acts, which must be committed with specific intent, are: killing members of the group; causing serious bodily or mental harm to the members of the group; deliberately inflicting on the group conditions of life calculated to bring about its physical destruction in whole or in part; imposing measures intended to prevent births within the group; and forcibly transferring children of the group to another group. The Elements of Crimes elaborates that these acts must be part of a manifest pattern of similar conduct, implying that the acts requiring specific intent must be part of a general plan or policy.

As will be seen in the next chapter with the UN Commission's investigation into the Darfur atrocities and the subsequent ICC Chief Prosecutor's investigation and prosecution of Sudanese President Al Bashir, some perpetrators may try to escape the charge of genocide due to this requirement of specific intent for the successful prosecution of genocide. Leaders may well be intimately involved in the mass slaughter of civilians and may be at the top of a command structure that carries out what could well be regarded as a genocide, but unless the specific intent to destroy a whole or a substantial or significant part of the group can be convincingly demonstrated before the Court, some of these most senior officials may well escape the charge of genocide. The Statute drafters decided not to alter this requirement of specific intent for the crime of genocide arising out of the wording of article II of the Genocide Convention and the jurisprudence of the ad hoc Tribunals. However, even if those who organize genocidal atrocities escape the charge of genocide, they will most likely be prosecuted successfully under the charge of crimes against humanity and possibly war crimes.

As evidenced in the case of Slobodan Milosevic, when there is potentially sufficient evidence to accuse a leader of a nation or militia of the "crime of crimes" charge of genocide under the ICC Statute, it is the beginning of a process of isolation by most of the international community of this individual and removing him from the conflict situation to face justice and thereby further the process of sustainable peace. Sometimes, just the charge of genocide accomplishes this situation even if, as again in the case of Milosevic, the individual escapes judgment by passing away or, as in the case of President Al Bashir, there is a preliminary failure to prove specific intent. 
Turning to subject matter jurisdiction, again we see a very complex balancing of not only national sovereignty with justice, but also allotting the primary place of peace and security and therefore global politics not to the Court but to the UN Security Council. This fact is often forgotten by the critics who accuse the Court of ignoring the place of peace in the pursuit of justice. These critics frequently ignore the fact that the jurisdiction of the Court can substantially only be triggered primarily by State Parties and the UN Security Council, who are thereby given the primary role to pursue non-judicial means to sustainable peace processes. The Prosecutor's independent ability to start an investigation proprio motu has been demonstrated not to be the main foundation of the ICC's caseload. However, as will be discussed in the case of the prosecution of high-level Kenyan officials, if those individuals are also operating the levers of government, a proprio motu investigation can be derailed with relative ease.

Under article 13 of the ICC Statute, the Court can only exercise jurisdiction over the defined crimes listed in three situations: first, where a "situation" regarding a specific conflict is referred to the Court and the Prosecutor by a State Party; secondly, where the UN Security Council acting under its Chapter VII powers relating to threats to international peace and security refers a situation to the ICC Prosecutor; thirdly, regarding jurisdiction, which was hotly contested by the US at the Rome Diplomatic Conference, where the Prosecutor can initiate an investigation on his own authority proprio motu in respect of the listed crimes.

The substantial part of the cases that have so far gone to trial comprise the first two heads of jurisdiction. Apart from the situation regarding the troubled prosecution of Kenyan high officials, originally with the consent of the former Kenyan government, and the authorization of the investigation in Côte d'Ivoire in 2011 before the country became a State Party in 2013, none of the ongoing investigations carried out under the proprio motu powers of the Prosecutor are the main situations that have triggered the so-called "peace versus justice" debate regarding the role of the Court and its mandate under the ICC Statute. Instead, as will be discussed in Chapters 3 and 4, much of the peace versus justice critique of the ICC surrounds a referral of the situation in Darfur, Sudan by the UN Security Council and the referral by Uganda regarding the actions of the Lord's Resistance Army in northern Uganda.

This form of jurisdiction of the ICC was the result of the strong coalition between the like-minded group of states, led by Canada and the NGOs at the Rome Diplomatic Conference, that managed to stave off the attempt by the US and other states that wanted a tribunal dominated substantially by the Security Council. These opponents of the proprio motu jurisdictions feared there could be political prosecutions started by a Prosecutor that would not be accountable to anyone. The final version of the ICC Statute would have proved this fear to be groundless as this power of the Prosecutor to see any investigation come 
to fruition, including issuing any arrest warrant or to have confirmation of the charges once the alleged perpetrator is arrested, is subject to the approval of a Pre-Trial Chamber. This insertion of a powerful judicial oversight, although very much in keeping with the civil law traditions around the world, must also be seen as a crucial part of alleviating concerns that national sovereignty would be subject to an unaccountable or overzealous Prosecutor.

Some of the African states, such as Chad, Kenya, Uganda and, most worryingly, South Africa, which have ratified the ICC Statute are endorsing the African Union opposition to the arrest warrants for Al Bashir and are contemplating non-cooperation (or in the case of South Africa, withdrawing from the Court). They seem to be forgetting their obligations under article 12(1) according to which State Parties do not have a choice as to whether to accept the jurisdiction of the Court, they are legally obliged to cooperate with the Court. 5

The complementarity principle adds further dimensions and complexity to the jurisdiction of the Court and the powers of the Prosecutor to investigate or prosecute a situation. The ability of the Prosecutor to investigate or prosecute a case is subject to a fundamental rule of admissibility that all relevant national court or state institutions are "unwilling or unable" to genuinely investigate or prosecute the same case. In other words, the Court is a global criminal court of last resort and can only seek jurisdiction if there is evidence that national authorities are attempting to shield the accused from any accountability for their grave criminal acts. This is in contrast to the ICTY and the ICTR, which had primacy over the national courts.

The concern to balance national sovereignty with the fight against impunity was most evident in the negotiations leading up to the ICC Statute. There was a consensus by states that the Court should only have jurisdiction if either there was an absence of national institutions willing and able to prosecute the most serious of international crimes or any such institutions were unwilling to do so or were even disposed to shield the perpetrator of the crimes. The result of the long and arduous negotiation was to give the Court jurisdiction under article 17 of the ICC Statute only where there was compelling evidence that demonstrated the following: (a) unwillingness to pursue the prosecution of the serious crimes, and any such proceedings, (b) were intended to shield the alleged perpetrator from responsibility, (c) were unjustifiably delayed, and (d) were not conducted independently or impartially and were conducted in a manner inconsistent with an intent to bring the person concerned to justice.

It should be kept in mind that while these criteria of unwillingness or inability to genuinely prosecute may seem to put the ICC in a position to sit in judgment on national judicial systems, in reality it would become obvious to the entire world that a national system would be failing these criteria if those who are alleged to have committed the most serious crimes known to humanity 
were able to escape the most basic forms of accountability known to most jurisdictions in the world.

In most cases, a national judicial system would fail the criteria when, as we shall see in the case of Sudan, those under indictment by the Court are not only immune from prosecutions but are given promotions or are summarily released after a brief detention. Article 17 defines the parameters of complementarity and offers another likely situation of the Court taking jurisdiction, where the state is unable to obtain the accused or the necessary evidence and testimony or otherwise unable to carry out the proceedings because there has been a total or substantial collapse or unavailability of the national judicial system.

As will be discussed in subsequent chapters, the ICC has commenced investigations and prosecutions in seven African countries. What seems to have been forgotten by the critics who accuse the Court of bias towards Africa is that in the majority of African countries involved, the situation was referred to the Court by the governments of the countries themselves. The Court accepted jurisdiction in the situations in northern Uganda, the Democratic Republic of Congo, the Central African Republic and in part in Côte d'Ivoire and Mali on the basis of referral by the governments of these countries. The situations in Sudan and Libya were, as the next chapter will reveal, referred to the ICC by the UN Security Council. This record of the Court's prosecutorial strategy has so far reinforced the fact that the ICC is a court of last resort. It is a logical conclusion that the referring African countries would not have referred their country situations to the Court if it had been felt that their prosecutorial and judicial systems were capable of prosecuting those alleged to have committed serious international crimes within their jurisdictions. For example, it is hard to rebut the presumption that the Democratic Republic of Congo had determined that its own prosecutorial and judicial systems were not capable of prosecuting the Congolese militia leader Lubanga Dyilo, who stood accused of serious crimes under the ICC Statute and is now convicted of those same crimes, as discussed in Chapter 2.

As an added layer of protection of national sovereignty, not only must the Prosecutor of the Court decide that there is no national judicial system that is willing and genuinely able to prosecute the alleged serious crimes, he or she must also convince a Pre-Trial Chamber of the Court that there is sufficient evidence to support the Prosecutor's position on complementarity.

In such situations, confirmed by both the investigations by the Prosecutor and the decision of the Pre-Trial Chamber, there is less likely to be a choice between peace and justice. The fact of the total breakdown or incapability of any form of impartial judicial system or the manipulation of the judicial system by the perpetrators or their allies in a state where there is violent conflict would be a strong indicator that the prospect of negotiations leading to a sustainable peace would be very slim. 
Impunity is most rampant around the world when it occurs at the highest levels of government, especially when it involves the Head of State. When such impunity exists in the middle of violent conflict, it is the situation that often gives rise to the gravest of violations of humanitarian law standards as codified under the ICC Statute.

When such impunity occurs, there is a very slim chance of any prospect of a durable peace. The ICTY and the ICTR drafter understood this fact and provided that " $\mathrm{t}]$ he official position of any accused person, whether as Head of State or Government or as a responsible Government official, shall not relieve such person of criminal responsibility nor mitigate punishment.' Such provisions were a legacy of the Nuremberg Charter, which also removed any immunity from the core Nazi leaders in Germany and, as discussed, was a method of preventing the exacting of vengeance against these leaders in the cause of using trial and punishment as prevention and a foundation for a durable peace in Europe.

These reasons for not affording immunity to Heads of State and high government officials found its way into the ICC Statute, which asserts in article 27 the legacy of the Nuremberg trials in the following words:

1. This Statute shall apply equally to all persons without any distinction based on official capacity. In particular, official capacity as a Head of State or Government, a member of a Government or a government official shall in no case exempt a person from criminal responsibility under this statute, nor shall it, in and of itself, constitute a ground for reduction of sentence.

2. Immunities or special procedural rules which may attach to the official capacity of a person whether under national or international law, shall not bar the Court from exercising its jurisdiction over such a person

The reason why this provision is of such importance is that, until the Nuremberg Charter, traditional notions of state sovereignty and, under international law, sovereign immunity was an ironclad defence, especially for Heads of State, while other officials asserted various forms of immunities when they acted in accordance with superior orders. These concepts of international law were major obstacles to the fight against impunity for grave international crimes. Under traditional customary international law, until the Nuremberg Charter, the Head of State was seen as the personification of the sovereign state and so was entitled to absolute immunity while other high state officials were considered to have functional immunities. 5 The ICJ has ruled that, regarding national courts exercising universal jurisdiction, customary rules still afford various levels of sovereign immunity to Heads of State and high foreign officials.

There is a strong argument to be made that holding Heads of State and high government officials accountable and punishable for serious international crimes is critical for preventing such crimes and promoting the foundations of 
a durable peace in troubled societies. The legacies of the two ad hoc Tribunals are especially important in this respect. The indictments by the ICTY of the Yugoslav President Slobodan Milosevic together with the first President of the Bosnian Serbs, Radovan Karadžić and General Ratko Mladić of the Bosnian Serb army were crucial to ending the conflict in this troubled region. Holding them accountable for the most serious of international crimes under article 7 of the ICTY Statute was critical to demonstrate that they were the architects of a policy and program of genocide and ethnic cleansing at the highest levels of government. On November 22, 2017, the so-called "Butcher of Bosnia" Ratko Mladić was sentenced to life in prison after being found guilty of genocide for atrocities committed during the Bosnian war from 1992 to 1995, including the slaughter of 8,000 men and boys in Srebrenica. ${ }^{6}$ Justice for his victims had to wait for a long time, but impunity for his crimes was denied.

Likewise, the prosecution and conviction by the ICTR of Jean Kambanda, the former Prime Minister of Rwanda, for participating in genocide and crimes against humanity was also deemed critical to the national reconciliation process in the aftermath of the genocide in that country. Kambanda had also acted at the highest levels of government and through the media to plan and incite the genocide against the Tutsi population and moderates in the Hutu hierarchy. 6

The ad hoc Tribunals regarded, and indeed the ICC can also regard, the involvement of Heads of State and high government officials in the most serious international crimes as aggravating factors in determining punishments. 6

Making Heads of State and high government officials accountable for involvement in the most serious international crimes is indispensable to the prevention of future conflicts and the deterrence of such crimes. Indeed, the legal duty of all states to cooperate in bringing these individuals to justice has reached the level of obligato erga omnes, a universal duty on every state in the world.

Those who are supporting the impunity of Heads of State and high government officials indicted by the ICC should bear this mind, as the next two chapters will discuss in the context of the ICC arrest warrants in Sudan.

In the debate over whether justice is reconcilable with the pursuit of peace in the mandate and present work of the ICC, one provision of the ICC Statute catches the attention of those who claim that the Court can avoid upsetting any negotiations for peaceful settlement of violent conflicts. Article 53(1) of the ICC Statute states that if the Prosecutor is satisfied that there is a reasonable basis to initiate an investigation and believes that the case is within the jurisdiction of the Court and is or would be admissible under article 17 of the Statute, he or she must determine whether, taking into account the gravity of the crime and the interests of the victims, "there are nonetheless substantial 
reasons to believe that an investigation would not serve the interests of justice.' 1 Article 53(2) then addresses the initiation of a prosecution after an investigation has produced sufficient evidence to proceed. The provision states that upon investigation, the Prosecutor may conclude that there is not sufficient basis to proceed because "it is not in the interests of justice, taking into account all the circumstances, including the gravity of the crime, the interests of the victims and the age or infirmity of the alleged perpetrators, and his or her role in the alleged crime.'

These provisions could present the most challenging and complex aspects of the ICC mandate and throw the debate over the respective roles of peace and justice at the ICC into the forefront of headlines around the world. This is especially the case if Heads of State, who are supposed to be the guarantors of peace in their country, are the target of any investigation and prosecution. As will be discussed in the next chapter, this debate was triggered with full fury in the context of the arrest warrant for the President of Sudan, Omar Al Bashir.

Surprisingly, there is no clear explanation in the ICC Statute itself as to what the objective of the phrase "interests of justice" was intended to be, even though the phrase appears in key areas of the Statute and the Rules of Procedure and Evidence. However, as will be discussed, the mandate of the Prosecutor under the ICC Statute and the very purpose of the establishment of the Court, as evidenced in the preamble to the Statute, can provide the most significant guidance.

In the structure of the mandate and operations of the Office of the Prosecutor, the interests of justice consideration can occur only after determinations on both jurisdiction and admissibility. These are very heavy thresholds that the Prosecutor must cross before he or she can find a reason not to proceed in the interests of justice. The Office of the Prosecutor is focused on investigating and prosecuting the most serious crimes of concern to the international community. For any situation to be admissible, not only do the alleged crimes have to be those within the jurisdiction of the Court, but they also have to be of "sufficient gravity to justify further action" under article 17(1)(d). 1 The Office of the Prosecutor has asserted that, in determining whether any situation is of sufficient gravity, he or she will consider the scale of the crimes, the nature of the crimes, the manner of their commission, and their impact.

Therefore, even before considering whether there are substantial reasons to believe it is not in the interests of justice to initiate an investigation or commence a prosecution, there has already been a decision that evidence indicating the gravity of the alleged crimes against humanity, war crimes, or genocide is actually or potentially very high, is admissible under the criteria laid down in the Statute, and that there are sufficient grounds to proceed with the investigation or prosecution. This means that the reference to the "gravity of the crime" as one of the explicit factors to be considered in determining the interests of 
justice must lead to a strong presumption against any extraneous factor, such as potential peace negotiations, being taken into account in determining when it is in the interests of justice not to proceed with an investigation or prosecution. This strong presumption is even stronger if there is any demand not to proceed with a prosecution in the interests of justice. The preliminary investigation will have produced sufficient evidence of the gravity of the crimes that would make it very difficult to put aside such evidence and forget about it in the interests of justice.

This conclusion is reinforced by the objectives and purpose of the ICC Statute itself as stated in the preamble. Paragraph 4 of the preamble confirms the intention of the State Parties to put an end to impunity for the perpetrators of the most serious crimes of concern to the international community and thus to contribute to their prevention. Likewise, the last paragraph confirms the resolve of State Parties to guarantee lasting respect for and the enforcement of international justice. These are surely overwhelming aspects of the interests of justice in addition to the obligatory standards imposed on the mandate and operations of the Prosecutor. Such a conclusion can sometimes be regarded as clashing with the potential for peaceful settlement of violent conflicts where the most serious of international crimes are alleged to have been committed. Nevertheless, the ICC Statute imposes a regime of law and the rule of law, not one which is subject to the shifting winds of politics and political expediency. It is for these reasons that the Prosecutor has not yet made a decision to investigate or not proceed with a prosecution after determining that it would not be in the interests of justice. 4

As will be discussed in the next chapters, there is also a grave danger that those who are alleged to have committed the most serious of international crimes could use the prospect of peace negotiations to escape any form of investigation and prosecution, thereby creating a form of impunity by interminable peace negotiations which may never succeed. This has become most contentious in the context of the investigations and prosecutions in Darfur, Sudan and northern Uganda, as Chapters 3 and 4 will discuss. In both cases, the alleged perpetrators seemed to develop a strategy of interminable negotiations, which may well have been programmed in advance for failure.

Another explicit factor the Prosecutor is to consider under article 53 in determining whether the interests of justice should prevail over any investigation or prosecution is the interests of victims. Accounting for the interests and participation of victims who, under the ICC Statute, are able to present their views and concerns to the Court has been regarded as one of the most unique and historic features of the ICC, unparalleled in the history of international criminal tribunals.

Considering the interests of victims will often require taking into account conflicting perspectives of victims. While undoubtedly some will argue stren- 
uously for investigations and prosecutions for the most serious international crimes based on compelling evidence to go ahead, the views of other victims could well diverge. The Prosecutor has faced these divergent views of victims in virtually all the investigations and prosecutions to date and no doubt will do so in all future ones. Because investigations and subsequent prosecutions will often involve the world's most dangerous places, the interests of victims will also focus on their safety, physical and psychological well-being and dignity, and the privacy of victims who are also likely to be witnesses as required by articles 68(1) and 54(1)(b) of the ICC Statute. Indeed, the Registry of the ICC has established a Victims and Witnesses Unit that focuses on ongoing risk assessments for victims and witnesses. Ultimately, to properly assess the interests of victims and victim witnesses, the Prosecutor must conduct extensive consultations with a wide range of individuals, groups and other stakeholders beyond the identified group of victims.

The Office of the Prosecutor followed this approach in the situation in northern Uganda, making more than 25 missions to the region to gather the various views and interests of victims, and has established extensive protective measures for victims and potential witnesses. However, this did not lead to the Prosecutor deciding to terminate any investigations or prosecutions regarding the indicted alleged perpetrators in northern Uganda in the interests of justice.

As will be clear from Chapter 4, even though many victims may have wished to have the investigations and prosecutions stopped in the hope of a peace agreement, it was again clear that the main perpetrators were using that hope to implement a form of impunity under the façade of seeking peace.

Finally, the Prosecutor is also entitled to consider the particular circumstances of the accused as described in article 53(2)(c). The interests of justice will not be served in this regard if, for example, the accused is terminally ill or himself the victim of serious crimes or human rights violations. The continuation of any investigation or prosecution in such a case would not be in accordance with the objective of the Court, as enunciated in the preamble, to achieve lasting respect for and the enforcement of international justice.

Article 53 does not provide an exhaustive list of considerations for the Prosecutor to consider what may be in the interests of justice in determining whether to begin an investigation or prosecution, but it is subject to the parameters described above. Given the high threshold of jurisdiction and admissibility, there is a strong presumption in favour of seeking accountability for the most serious of crimes. This is not to downplay the importance of other forms of accountability pursued by other groups and individuals. The Office of the Prosecutor has endorsed and supported other forms of genuine and effective strategies to combat impunity. These include the vital role to be played by domestic prosecutions for individuals lower down the hierarchy of organizations who have planned and implemented the serious crimes and tradi- 
tional justice mechanisms such as truth commissions and reparation programs. These alternative forms of seeking redress for acts of impunity are exceedingly valuable forms of complementary mechanisms for the ICC to ensure that what is termed the "impunity gap" is addressed.

These interpretations of the interests of justice based on the objectives of the ICC Statute and the mandate and operations of the Office of the Prosecutor have not stopped critics of the Court, who allege that in some situations the ICC has acted to subvert ongoing peace processes. This reached a zenith in the case of the prosecutions and arrest warrants in northern Uganda and Sudan.

Former UN Secretary-General Kofi Annan stated that "justice, peace and democracy are not mutually exclusive objectives, but rather mutually reinforcing imperatives.' 10 He stated this in the context of a report on recommendations requested by the UN Security Council at a meeting in January of 2006 on post-conflict national reconciliation and the role of the UN. He argued that approaches focusing only on one or another institution, or ignoring civil society or victims, will not be effective.

In keeping with these views of the UN Secretary-General, justice versus peace cannot be viewed as a zero-sum game. Indeed, both are partners in the process of establishing a sustainable peace in the troubled regions of our world. If peace and justice are indeed such partners, then there must be an institutional division of labour in terms of which organizations and institutions promote justice and which ones promote peace.

The mandate of the ICC is to combat impunity for the most serious of crimes known to humanity. In very exceptional circumstances it can desist from doing so in the interests of justice as discussed above. The concept of the interests of justice cannot be taken to encapsulate the entire gamut of issues relating to peace and security in conflict zones. To do so would turn the ICC from a judicial body to a global political body and, as discussed throughout this chapter, severely hinder the justice role played by the Court in preventing future conflicts and promoting sustainable peace through that function. Indeed, the Statute recognizes this institutional division of labour on justice and peace.

The Office of the Prosecutor and the Court are bound by the mandates given to them by the ICC Statute. These mandates are focused on the law relating to the fight against impunity and the need to ensure that serious crimes do not go unpunished. The agenda for peace given to the ICC stipulated in its preamble that if such crimes do go unpunished it threatens the peace, security, and well-being of the world. The statement by Adolf Hitler on the forgotten Armenian genocide is conclusive proof of this peace agenda of the ICC.

This does not mean that the ICC will not be involved in situations that call for attention to be paid to the larger political context and the potential for peace through political negotiations. That larger context is not, however, the role 
given to the ICC by its Statute. Instead, the Statute offers that role to the UN Security Council.

There is the ability under the ICC Statute for the UN Security Council to "trump" the law and justice role of the Court by deferring any investigation or prosecution by the ICC where it considers it necessary for the maintenance of international peace and security.

Article 16 of the Statute states that

no investigation or prosecution may be commenced or proceeded with under this Statute for a period of 12 months after the Security Council, in a resolution under Chapter VII of the Charter of the United Nations, has requested the Court to that effect; that request may be renewed by the Council under the same conditions.

The African Union requested the Security Council to defer the prosecutions against Kenyan President Uhuru Kenyatta and Vice-President William Ruto for one year, allegedly to permit the government to deal with a major attack by Al Qaeda-linked Somali militants at a shopping mall. However, on November 15, 2013, the Council denied the deferral. Significantly, Russia and China voted in favour of the deferral while eight nations, which surprisingly included France, the US, and the United Kingdom, abstained, preventing the requisite nine affirmative votes for the deferral. Such a divide in the Security Council on the fight against impunity would rear its ugly head again when the Council was asked to refer the atrocities in Syria to the ICC, as discussed in Chapter 6.

In the face of this rejection, on June 27, 2014, the African Heads of State at an African Union Summit in Equatorial Guinea voted to adopt an amendment to the African Union Charter that would grant incumbent government leaders and other senior officials immunity from prosecution in the African Court of Justice and Human Rights. This African Union betrayal of the fight against impunity also has the potential to attack the credibility of the African Court of Justice and Human Rights in its ability to adjudicate mass atrocities committed by African leaders.

Finally, it should be noted that under article 53, a decision by the Prosecutor not to investigate or prosecute made in the context of the interests of justice will only be effective if confirmed by the Pre-Trial Chamber, which may also on its own initiative review the same decision by the Prosecutor. The Prosecutor may also reconsider his or her decisions in this area based on new facts or information.

\section{NOTES}

1. Benjamin N Schiff, Building the International Criminal Court (Cambridge: Cambridge University Press, 2008) at 15-16. 
2. Hugo Grotius, "De Jure Belli Ac Pacis Libri Tres" in Benjamin B Ferencz, Enforcing International Law - A Way to World Peace, vol 1 (New York: Oceana Publications, 1985) at 137.

3. See Christopher Keith Hall, "The First Proposal for a Permanent International Criminal Court" (1998) 332 Intl Rev Red Cross 57.

4. Francis Lieber, Instructions for the Government of Armies of the United States in the Field, originally issued as General Orders No. 100 (Washington: Government Printing Office, 1898).

5. For the history and significance of the Martens Clause, see Theodor Meron, "The Martens Clause, Principles of Humanity, and Dictates of Public Conscience" (2000) 94:1 Am J Intl L 78.

6. Hilaire McCoubrey, International Humanitarian Law: Modern Developments in the Limitation of Warfare, 2nd ed (Aldershot: Ashgate, 1998) at 27-28.

7. Schiff, supra note 1 at 20-21.

8. William A Schabas, An Introduction to the International Criminal Court, 2nd ed (Cambridge: Cambridge University Press, 2004) at 4.

9. For a historical record of the Armenian genocide, see Armenian National Institute, "Adolf Hitler, Chancellor of Nazi Germany (1933-45)," online: www.armenian -genocide.org/hitler.html.

10. There were few actual trials held in Germany and minimal sentences handed down. They were perceived as a failure of this early attempt to establish an international criminal justice process: Schabas, supra note 8 at 4.

11. Treaty of Peace between the Allied and Associated Powers and Germany, 28 June 1919 at art 227, online: https://www.loc.gov/law/help/us-treaties/bevans/m -ust000002-0043.pdf.

12 Gary Jonathan Bass, Staying the Hand of Vengeance: The Politics of War Crimes Tribunals (New Jersey: Princeton University Press, 2000) at 157.

13. Schabas, supra note 8 at 9.

14. See Final Report of the Commission of Experts established pursuant to Security Council Resolution 780 (1992), UNSCOR, 27 May 1994, UN Doc S/1994/674 at Annex II, IX, IX(A), IX(B). See also Bola Ajbola, "Human Rights in the Federation of Bosnia-Herzegovina" (1997) 12:2 Conn J Intl L 189; David M Kresock, "'Ethnic Cleansing' in the Balkans: The Legal Foundations of Foreign Intervention" (1994) 27:1 Cornell Intl LJ 203; Theodor Meron, "Rape as a Crime under International Humanitarian Law" (1993) 87:3 Am J Intl L 424.

15. Report of the Secretary-General pursuant to General Assembly Resolution 53/35, The Fall of Srebrenica, UN GAOR, 54th Sess, 15 December 1999, UN Doc $\mathrm{A} / 54 / 549$.

16. International Criminal Tribunal for the Former Yugoslavia, SC Res 808, UNSCOR, 22 February 1993, UN Doc S/RES/808 [ICTY Res 808].

17. Statute of the International Criminal Tribunal for the Former Yugoslavia, SC Res 827, UNSCOR, 25 May 1993, UN Doc S/Res/827 [ICTY Statute].

18. Report of the Independent Inquiry into the actions of the United Nations during the 1994 Genocide in Rwanda, UNSCOR, 15 December 1999, UN Doc S/1999/1257 at 51.

19. Statute of the International Criminal Tribunal for Rwanda, SC Res 955, UNSCOR, 8 November 1994, UN Doc S/RES/955 at Annex [ICTR Statute].

20. ICTY Res 808, supra note 16; ICTR Statute, supra note 19.

21. International Criminal Tribunal for the former Yugoslavia, "About the ICTY," online: www.icty.org/en/about. 
22. ICTR Statute, supra note 19 at 1.

23. United Nations International Residual Mechanism for Criminal Tribunals, "The ICTR Remembers," online: www.unmict.org/specials/ictr-remembers/?q=ictr -remembers/.

24. Theodor Meron, "War Crimes in Yugoslavia and the Development of International Law" (1994) 88:1 Am J Intl L 78 at 79.

25. See e.g. Leila Nadia Sadat, "The Legacy of the ICTY: The International Criminal Court" (2003) 37:4 New Eng L Rev 1073 at 1074.

26. Ibid at 1074-78. See also Yoram Dinstein, "Case Analysis: Crimes Against Humanity After Tadić" (2000) 13:2 Leiden J Intl L 373.

27. Human Rights Watch, Selling Justice Short: Why Accountability Matters for Peace (New York: Human Rights Watch, 2009) at 25-27.

28. Ibid at 20-25.

29. Ibid at $117-22$.

30. See Emina Dizdarevic, "Hague Tribunal Shares Lessons of War Crime Probes," Balkan Transnational Justice (23 June 2017), online: www.balkaninsight.com/ en/article/hague-tribunal-mulls-lessons-of-war-crime-probes-06-23-2017 ["Prosecutors from the International Criminal Tribunal for the Former Yugoslavia told a conference in Sarajevo about how they developed investigations into war crimes perpetrators and those who commanded them"].

31. For case details including convictions, sentences and acquittals, see "International Criminal Tribunal for the Former Yugoslavia," online: www.icty.org. For an extensive discussion of the legacy of the ICTY by the world's leading judges, prosecutors and academics in the closing ceremonies and legacy conferences, see also International Criminal Tribunal for the former Yugoslavia, "ICTY Legacy Dialogues," online: www.icty.org/en/features/icty-legacy-dialogues.

32. Agreement between the United Nations and the Government of Sierra Leone on the establishment of a Special Court for Sierra Leone, 16 January 2002, 2178 UNTS 137 (entered into force 12 April 2002).

33. Witness to Truth: Report of the Sierra Leone Truth \& Reconciliation Commission (Accra, Ghana: Graphic Packaging, 2004) vol 3B at 86.

34. See Suzannah Linton, "Cambodia, East Timor and Sierra Leone: Experiments in International Justice" (2001) 12:2 Crim LF 185 at 190; see also Agreement between the United Nations and the Royal Government of Cambodia concerning the prosecution under Cambodian law of crimes committed during the period of Democratic Kampuchea, 6 July 2003, 2329 UNTS 117 art 1 (entered into force 29 April 2005).

35. "Cambodia: First Trial to Test Tribunal's Credibility: Court's Independence Remains a Concern as Khmer Rouge Trials Begin," Human Rights Watch (14 February 2009), online: www.hrw.org/news/2009/02/14/cambodia-first-trial-test -tribunals-credibility.

36. See Seth Mydans, "11 Years, $\$ 300$ Million and 3 Convictions. Was the Khmer Rouge Tribunal Worth It?," The New York Times (10 April 2017), online: https:// www.nytimes.com/2017/04/10/world/asia/cambodia-khmer-rouge-united-nations -tribunal.html.

37. Ibid. See generally Extraordinary Chambers in the Courts of Cambodia, "Case Load," online: https://www.eccc.gov.kh/en/case-load.

38. Mydans, supra note 36.

39. Taina Jarvinen, "Human Rights and Post-Conflict Transitional Justice in East Timor" (2004) 47 UPI Working Papers. 
40. See International Bar Association, "Special Panel for Serious Crimes (East Timor)," online: https://www.ibanet.org/Committees/WCC_EastTimor.aspx.

41. For a detailed discussion of the origins of some of the key provisions of the ICC Statute during the negotiations, see Adriaan Bos, "From the International Law Commission to the Rome Conference (1984-1998)" in Antonio Cassese, Paola Gaeta \& John RWD Jones, eds, The Rome Statute of the International Criminal Court: A Commentary (Oxford: Oxford University Press, 2002).

42 United Nations Diplomatic Conference of Plenipotentiaries on the Establishment of an International Criminal Court, Report of the Preparatory Committee on the Establishment of an International Criminal Court, Addendum, UN Doc A/ Conf.183/Add.1 (1998).

43. Michael P Scharf, "The Politics Behind the U.S. Opposition to the ICC" (1999) 5 New Eng J of Intl \& Comp L Ann 1 at 3.

44. Ibid at 5 .

45. Case concerning Military and Paramilitary Activities in and against Nicaragua (Nicaragua $v$ United States of America), [1984] ICJ Rep 392.

46. Rome Statute of the International Criminal Court, 17 July 1998, 2187 UNTS 90 at art 17 [ICC Statute].

47. Scharf, supra note 43 at 3.

48. For an outstanding portrayal and analysis of the vitriolic and ideological attacks against the establishment of the Court by the Bush administration, led by then US State Department Official and later UN Ambassador John Bolton, see Erna Paris, The Sun Climbs Slow: Justice in the Age of Imperial America (Toronto: Alfred A Knopf, 2008) at ch 4.

49. Schabas, supra note 8 at 54.

50. There is a rich literature on the negotiations at the Rome Diplomatic Conference, see e.g. Roy S Lee, The International Criminal Court: The Making of the Rome Statute; Issues, Negotiations, Results (The Hague: Kluwer Law International, 1999); Philippe Kirsch \& John T Holmes, "The Birth of the International Criminal Court: The 1998 Rome Conference" (1998) 36 Can YB Intl Law 3.

51. ICC Statute, supra note 46 at preamble para 10.

52 The Crime of Aggression, ASP Res 6, 13th Plen Mtg (11 June 2010), RC/11; International Criminal Court, Press Release, ICC-ASP-20171214-PR1350 "Assembly Activates Court's Jurisdiction over Crime of Aggression" (15 December 2017), online: www.icc-cpi.int/Pages/item.aspx?name=pr1350.

53. Sadat, supra note 25 at 1078-79.

54. Leila N Sadat \& Richard S Carden, "The New International Criminal Court: An Uneasy Revolution" (2000) 88:3 Geo LJ 381 at 458.

55. Kenneth S Gallant, "Jurisdiction to Adjudicate and Jurisdiction to Prescribe in International Criminal Courts" (2003) 48:3 Vill L Rev 763.

56. See Nicholas Kralev, "U.S. warms to Global Court," Washington Times (30 April 2009), online: https://www.washingtontimes.com/news/2009/apr/30/us-warms-to -global-panel.

57. ICC Statute, supra note 46 at art 10.

58. International Criminal Court, "Rome Statute and Other Agreements," online: https://asp.icc-cpi.int/en_menus/asp/RomeStatute/pages/default.aspx.

59. ICC Statute, supra note $\overline{4} 6$ at art 86 .

60. Ibid at art 17(1)a-d.

61. ICTY Statute, supra note 17 at art 9; ICTR Statute, supra note 19 at art 8.

62 ICTY Statute, supra note 17 at art 7(2); ICTR Statute, supra note 19 at art 6(2). 
63. ICC Statute, supra note 46 at art 27.

64. Charter of the International Military Tribunal: Annex to the Agreement for the Prosecution and Punishment of the Major War Criminals of the European Axis, 8 August 1945, 82 UNTS 251 at art 7 ["The official position of defendants, whether as Heads of State or responsible officials in Government Departments, shall not be considered as freeing them from responsibility or mitigating punishment"].

65. Sir Elihu Lauterpacht et al, International Law Reports (Cambridge: Cambridge University Press, 2006) vol 128 at 143.

66. Case Concerning the Arrest Warrant of 11 April 2000 (Democratic Republic of the Congo v Belgium), [2002] ICJ Rep 3.

67. Prosecutor $v$ Ratko Mladić, IT-09-92-T, Judgment (22 November 2017) (International Criminal Tribunal for the Former Yugoslavia, Trial Chamber I).

68. The Prosecutor $v$ Jean Kambanda, ICTR 97-23-A, Judgement (19 October 2000) (International Criminal Tribunal for Rwanda, Appeals Chamber), aff'g The Prosecutor v Jean Kambanda, ICTR 97-23-S, Judgment and Sentence (4 September 1998) (International Criminal Tribunal for Rwanda, Trial Chamber).

69. See e.g. The Prosecutor v Jean-Paul Akayesu, ICTR-96-4-A, Judgment (1 June 2001) (International Criminal Tribunal for Rwanda, Appeals Chamber), aff'g The Prosecutor v Jean-Paul Akayesu, ICTR 96-4-T, Judgement (2 September 1998) (International Criminal Tribunal for Rwanda, Trial Chamber).

70. Yusuf Aksar, Implementing International Humanitarian Law: From Ad Hoc Tribunals to a Permanent International Criminal Court (New York: Routledge, 2004) at 96.

71. ICC Statute, supra note 46 at art 17 (emphasis added).

72. Ibid at art 53(2) (emphasis added).

73. Ibid at art 17(1)(d).

74. Office of the Prosecutor, "Policy Paper on the Interest of Justice" (The Hague: International Criminal Court, 2007) at 4.

75. Ibid at 5-6.

76. Ibid.

77. Ibid at 7.

78. Ibid at 7-8.

79. United Nations, Press Release, SC/8209, "Security Council Stresses Importance, Urgency of Restoring Rule of Law in Post-Conflict Societies" (6 October 2004), online: UN Meetings Coverage \& Press Releases www.un.org/press/en/2004/ sc8209.doc.htm.

80. Ibid. 